Elena A. Cherenkova ${ }^{1 *}$, Nina K. Kononova ${ }^{1}$, Nadiya R. Muratova ${ }^{2}$

${ }^{1}$ Institute of Geography, Russian Academy of Sciences; Staromonetny per., 29,

Moscow, Russia 119017; Tel.: (499) 1290474, fax (495) 9590033

* Corresponding author; e-mail: Icherenkova@marketresearch.ru

${ }^{2}$ National Center for Space Research and Technology; Shevchenko str., 15, Almaty,

Republic of Kazakhstan 050010

\title{
SUMMER DROUGHT 2010 IN THE EUROPEAN RUSSIA
}

\begin{abstract}
In this paper, we investigate the spatial and temporal characteristics of the spring-summer atmospheric drought using various indicators from the meteorological station observations in the European Russia in May - August 2010.
\end{abstract}

Drought indicators suggest that the drought 2010 was not the most extensive. Weather conditions in the winter and spring of 2010 contributed to the occurrence of dry conditions in the central part of European Russia in May. It has been found that the most impact of the severe drought was on the territory of the Volga region. Drought began in May and lasted for 4 months. The intensity of severe and extreme drought increased from May to August. In the south of European Russia, severe and extreme drought was observed.

Analysis of the macrocirculation conditions of the drought formation has shown the likelihood of its occurrence in the European Russia in the near future.

KEY WORDS: drought, Selyaninov hydrothermal coefficient, Palmer Drought Severity Index, Soil Water Index, European Russia

\section{INTRODUCTION}

Drought as a hazardous natural phenomenon is determined primarily by meteorological factors. Although there have been many regional Russian drought studies, the researchers continue to examine drought conditions, frequency, and duration of climate-caused drought periods, especially in the grain-producing regions of Russia [Drozdov, 1980; Zoidze \& Khomyakova, 2000; Zolotokrylin et al., 2007; Loginov, 2002; Meshcherskaya et al., 2011; Semenov, 2012; Rauner, 1981; Ulanova\& Strashnaya, 2000]. Severe drought of 2010 in European Russia was the cause of new scientific studies [Volodin, 2011; Ivanova et al., 2011; Mokhov, 2011; Frolov \& Strashnaya, 2011; Barriopedro et al., 2011; Blunden et al., 2011; Grumm, 2011; Lau \& Kim, 2012; Schubert et al., 2011]. Research interest is caused by a negative influence of drought on agricultural productivity and instability of characteristics of the dry periods in a changing climate.

Meteorologically connected recordbreaking extreme events were observed during the summer of 2010: a heat wave and wildfires in European Russia and the severe flood in Pakistan. Drought was caused by an extraordinarily strong and prolonged extratropical atmospheric blocking event in association with a large-scale atmospheric Rossby wave spanning over European Russia, Kazakhstan, and the northwestern China-Tibetan Plateau region. The heat wave was amplified by a positive feedback through changes in the surface energy fluxes between the atmospheric blocking pattern and land with below-normal soil moisture [Lau and Kim, 2012]. Anomalously heavy rain events over northern Pakistan occurred due to the southward penetration of extratropical potential vorticity in the deep trough east of the European blocking [Galarneau et al., 2012; Hong et al., 2011]. The discussion 
about the connection between the events of summer 2010 with the anthropogenous climate change is not complete. On the one hand, the natural variability of climate was the main cause of the heat wave in European Russia [Dole et al., 2011]. On the other hand, the record heat in July 2010 would not have happened without the large-scale climate warming [Rahmstorf \& Coumou, 2011].

The authors investigated the genesis and dynamics of hazardous atmospheric drought (criteria recommended by the Hydrometeorological Research Center of Russia) and its conjunction with the macrocirculation processes in the 20 - early 21 century over the European Russia in their previous studies [Cherenkova, 2007; Cherenkova, 2012; Cherenkova \& Kononova, 2012].

Some papers claimed that: 1) severe and extreme drought in 2010 was manifested in the south of European Russia and 2) drought like the drought in 2010 was not observed in the European part of Russia for 75 years of instrumental meteorological observations [Meshcherskaya et al, 2011; Frolov \& Strashnaya, 2011].

The goal of this study is to identify the spatial and temporal characteristics of the springsummer atmospheric drought in May August 2010 over the European part of Russia using quantitative indices of drought. We also sought to answer the question, what was the area of extreme drought in 2010, compared with similar droughts in European Russia in the XX - early XXI-st century. This paper is focused on the investigation of regional peculiarities of spring and summer atmospheric drought with the emphasis on the study of severe and extreme drought and macrocirculation conditions of its formation as an event with the greatest negative impact on agricultural production.

\section{DATA AND METHODOLOGY}

The identification of atmospheric drought on the plains of European Russia from May to
August, 2010, is based on the well-known, in Russian Federation, Selyaninov Hydrothermal Coefficient (HTC) and the most widely used, in the USA, the Palmer Drought Severity Index (PDSI).

The Hydrothermal Coefficient is calculated as

$H T C=P / 0,1 \cdot T_{>10^{\circ} \mathrm{C}}$

where $T_{>10^{\circ} \mathrm{C}}$ is the sum of daily mean air temperature in the period with daily temperature above $10^{\circ} \mathrm{C}, \mathrm{P}$ is the daily precipitation sum over the same period [Selyaninov, 1928]. Fora more consistentzonal comparison of the results, we considered the normalized standard deviation anomalies of HTC [Zolotokrylin \& Titkova, 2012].

In this work, we used the data set VNIIGMI MTsD on observations of air temperature and the daily total precipitation for 19362010 (www.meteo.ru) for calculation of the Hydrothermal Coefficient. Results were obtained from the data of 44 weather stations located in European Russia. Anomalies and the standard deviation of the normalized HTC anomalies were evaluated in comparison with the average for the period 1936, 2010. The monthly gridded global PDSI values $\left(2,5^{\circ} \times 2,5^{\circ}\right.$ resolution) are taken from the global dataset [Dai et al., 2004]. The Palmer Drought Severity Index is based on the use of empirical coefficients for calculating the regional water resources, standardized to the local climate. The index is the sum of the current moisture anomaly and combined with weighting factors of previous values of the index. Moisture anomaly is defined as:

$d=P-\hat{P}$,

where $P$ - the monthly amount of precipitation, $\hat{P}$ - potential values climatically appropriate for existing conditions (CAFEC) [Palmer, 1965]. The definition of $\hat{P}$ is a simple analog of the water balance equation:

$\hat{P}=\alpha_{i} P E+\beta_{i} P R+\gamma_{i} P R O-\delta_{i} P L$. 
The weighting factors are called the waterbalance coefficients and are found in the following manner:

$$
\begin{array}{cc}
\alpha_{i}=\frac{\overline{E T_{i}}}{\overline{P E_{i}}} & \beta_{i}=\frac{\overline{R_{i}}}{\overline{P R_{i}}} \\
\gamma_{i}=\frac{\overline{R O_{i}}}{\overline{P R O_{i}}} & \gamma_{i}=\frac{\overline{R O_{i}}}{\overline{P R O_{i}}}
\end{array}
$$

where $i$ ranges over the months of the year, $\overline{E T}$ - evapotranspiration, $\bar{R}$ - recharge, $\overline{R O}$ - runoff, $\bar{L}$ - loss, $\overline{P E}$ - potential evapotranspiration, $\overline{P R}$ - potential recharge, $\overline{P R O}$ - potential runoff, $\overline{P L}$ - potential loss. The bar over a term indicates an average value, which depend on the available water holding capacity (AWC).

The moisture departure is weighted using $K$ for comparability of the index values in the different months of the year in different locations. Kis called the climatic characteristic and defined as:

$$
K_{i}^{\prime}=1.5 \log _{10}\left(\frac{\frac{\overline{P E_{i}}+\overline{R_{i}}+\overline{R O_{i}}}{\overline{P_{i}}+\overline{L_{i}}}+2.8}{\overline{D_{i}}}\right)+0.5
$$

$$
K_{i}=\frac{17.67}{\sum_{j=1}^{12} \overline{D_{j}} K_{j}^{\prime}} K_{i}^{\prime}
$$

where $\bar{D}_{j}$ is the average of the moisture anomaly for month $j$.

As a result, we obtain the Palmer moisture anomaly index ( $Z$ index):

$Z=K d$

$Z$ index can indicate wet or dry conditions during a single month without regard to a recent trend of the ratio of heat and moisture.

Monthly values of the Palmer Drought Severity Index are calculated as:

PDSI $_{i}=0,897 \cdot$ PDSI $_{i-1}+Z_{i} / 3$.

The advantages of this methodology are demonstrated in the comparability of the values in any place and at any time of year, as well as in the ability to take into account the moisture conditions in previous months. The inability to account for evapotranspiration of frozen ground and snow accumulation limits the index usage [Alley, 1984].

The area was calculated as the percentage area of the drought from the area of research territory (\%). The intensity of the drought or its severity is reflected in an identified type of drought (Table 1). Analysis of the area and intensity of drought in European Russia showed that the area and intensity correlate with a coefficient of 0,98 for the normalized HTC anomalies and 0,96 for the Palmer Drought Severity Index.

To analyze the long-term fluctuations of global atmospheric circulation we applied the classification of elementary circulation mechanisms (ECMs) for the Northern Hemisphere developed by B.L. Dzerdzeevskii [Dzerdzeevskii, 1962; Dzerdzeevskii, et al., 1946]. The results obtained using this classification (the long-term series of alternations of ECM, patterns of circulation, most recent publications, list of all publication where this classification was used) during the period from 1899 to present are placed on the website www.atmosphertccirculation.ru [Kononova, 2009].

Table 1. Classification of the drought intensity

\begin{tabular}{|c|c|c|}
\hline Severity classes & Normalized HTC anomaly & Palmer Drought Severity Index \\
\hline Mild drought & -1.00 to -1.24 & -1.00 to -1.99 \\
Moderate drought & -1.25 to -1.49 & -2.00 to -2.99 \\
Severe drought & -1.5 to -1.74 & -3.00 to -3.99 \\
Extreme drought & Below -1.75 & Below -4.00 \\
\hline
\end{tabular}


Table 2. The distribution of drought -related ECMs in the circulation groups for European Russia

\begin{tabular}{|c|c|l|c|}
\hline Western zonal & Northern meridional & Southern meridional & Stationary position \\
\hline $2 \mathrm{a}, 2 \mathrm{v}, 6,7 \mathrm{al}, 7 \mathrm{bl}$ & $\begin{array}{c}4 \mathrm{~b}, 4 \mathrm{v}, 8 \mathrm{bl}, 8 \mathrm{gl}, 8 \mathrm{gz}, 10 \mathrm{a}, \\
10 \mathrm{~b}, 12 \mathrm{a}, 12 \mathrm{bl}, 12 \mathrm{vl}\end{array}$ & $2 \mathrm{~b}, 8 \mathrm{bl}$ & $3 \mathrm{a}, 9 \mathrm{a}, 9 \mathrm{~b}, 13 \mathrm{l}$ \\
\hline $\begin{array}{l}\text { The propagating edge of } \\
\text { the Azores anticyclone }\end{array}$ & $\begin{aligned} \text { The Arctic air intrusions } \\
\text { The outputs of the } \\
\text { Mediterranean cyclone } \\
\text { tracking }\end{aligned}$ & $\begin{array}{l}\text { Persisting anticyclone in } \\
\text { the region }\end{array}$ \\
\hline
\end{tabular}

1. Zonal ECMs for the Northern Hemisphere without blocking events with three outputs of the Mediterranean cyclone tracking: $2 \mathrm{a}$ - towards Central and Western Europe, along the Pacific coast, across North America; $2 \mathrm{~b}$ - from the Mediterranean via the Black Sea and Caspian Sea basins in the direction of the Volga and Ural basins along the Pacific coast and across North America; 2v - across the Caspian and Aral Sea in the direction of the Ob and Yenisei River basins, along the Pacific coast, across North America. 2) Disturbance of zonal circulation ECMs for the Northern Hemisphere: 3 - blocking anticyclone over the Atlantic; 4b - blocking event over European Russia; 4v - blocking event over the Urals and Western Siberia; 6 - blocking anticyclone in the Pacific sector; 7al - blocking event over the east of North America; $7 \mathrm{bl}$ - blocking event over the west of North America. 3) Northern meridional ECMs for the Northern Hemisphere. Two blocking events: $8 \mathrm{a}$ - over the east of North America and Western Europe; 8bl - over European Russia and Eastern Siberia; 8vl - over Eastern Siberia and the Pacific Ocean; 8gl - over the Atlantic and Western Siberia; 8gz - over the Atlantic and Eastern Siberia; 9a - over the Atlantic and Pacific Ocean; 10a - over European Russia and the east of North America; $10 \mathrm{~b}$ - over the east of European Russia and west of North America. $12 \mathrm{a}$ - four blocking events, one of them over European Russia. Three blocking events: 12bl - one of them over the sector from $40^{\circ} \mathrm{E}$ to $100^{\circ} \mathrm{E}$;; $12 \mathrm{vl}$ - one of them over the basin of the Volga and $\mathrm{Ob}$. 4) Southern meridional ECMs for the Northern Hemisphere: 131 - four outputs of the Mediterranean cyclone tracking.

There is an elementary circulation mechanism classification of cyclone and anticyclone finding and tracking scheme for six sectors - Atlantic, European, Siberian, Far East, Pacific and American sector [Dzerdzeevskii, 1968]. According to the cyclogenesis in the European sector $\left(0^{\circ}-60^{\circ} \mathrm{E}\right)$, the elementary circulation mechanisms (ECM) are grouped into: Western zonal group, Northern meridional group, Southern meridional group and Stationary position group (Table 2).

We also used the Soil Water Index (SWI) data set from satellite observations of the Institute of Photogrammetry and Remote Sensing (Vienna University of Technology) for evaluation of soil moisture anomalies in May-August 2010. The data with a resolution of $12,5 \mathrm{~km}$ are available for the period from 1992 without the gap period in 2001-2003 [Naeimi et al., 2009]. The Soil Water Index can be interpreted as the soil moisture content (\%) in the first 1 meter of the soil ranging between wilting level and field capacity. Soil moisture anomalies were calculated over the period 1992-2010.

\section{RESULTS AND DISCUSSION}

According to the normalized anomalies of the Selyaninov Hydrothermal Coefficient (as shown in Figure 1) large-scale drought covered $19 \%$ of the territory of European Russia in 1936, 22\% in 1938, 18\% in 1939, $38 \%$ in 1972, and $25 \%$ in 2010. According to the Palmer Drought Severity Index, a group of dry years was observed from 1936 to 1939 when the severe drought area increased from $35 \%$ (in 1936) to 42\% (in 1939). Extensive severe droughts in the European Russia were observed in 1972 (36\% of the territory), 1975 (20\%), 2002 (25\%) and 2010 (31\%). Extreme drought occupied less area, but was also extensive.

So, the greatest area of spring and summer strong drought in European Russia in the period 1936-2010 was in 1972 (according to the HTC normalized anomalies). The priority of the largest area of similar drought according to the Palmer Drought Severity Index was in 1939. This can be explained by the cumulative effect of several years of drought in the PDSI calculation.

Let's consider weather conditions in the European part of Russia in 2010. Winter was cold over large areas of European Russia. The highest mean monthly air temperature anomaly was observed in January over the central part of the territory (on average, 5 degrees lower than the historical average). In the south and west of the territory, the 


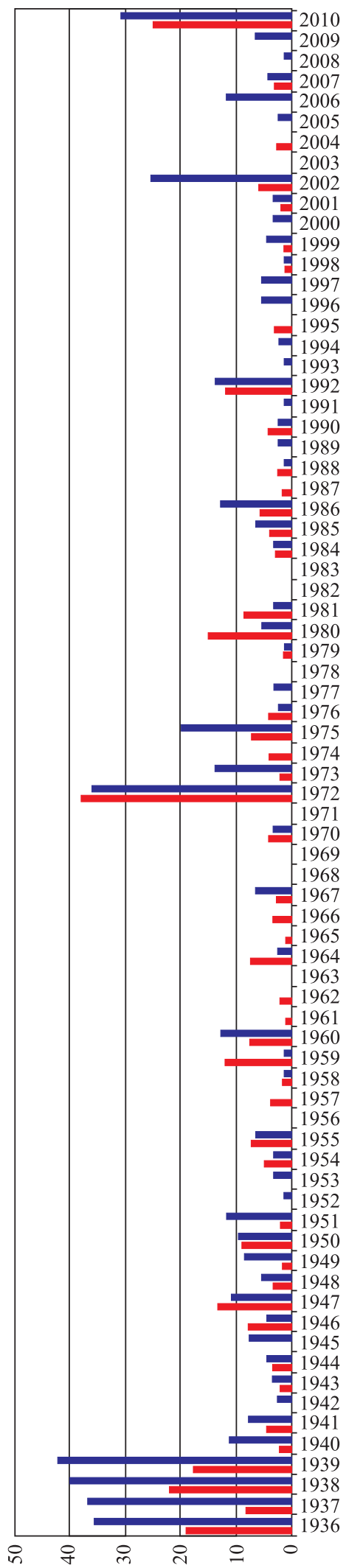

winter amount of precipitation almost twice exceeded the long-term average values (Table 3). On the contrary, spring was warm. A shortage of precipitation was in the center of European Russia (in April, $40 \%$ of the historical averages). Part of the winter precipitation decreased due to the abnormally cold winter and the deep soil freezing.

The genesis of the drought in May-August 2010, in the European Russia, is shown in Figures 2 and 3. It should be noted that although the intensity and extent of drought, according to both indexes, demonstrate small differences, the results based on the analysis of the PDSI values largely repeat those based on the normalized HTC anomaly variations due to a high correlation between them (correlation coefficients: 0,81 for the mild drought, 0,83 for the moderate drought, and 0,76 for the severe drought). This difference may reflect the contribution of moisture conditions of the previous periods into the PDSI calculation.

A persistent anticyclone formed over European Russia in early May due to the penetration of Arctic air. Recurring invasion of the Arctic cold air rapidly warmed over the continent and supplemented anticyclone throughout the month. As shown in Fig. 2a, the severe and extreme drought in 2010 occurred in May in a small area in the Volga region according to the PDSI values, and the severe drought began in June according to the normalized anomalies of the HTC (Fig. 3a). A severe drought spread in all directions during June-August, but the furthest to the south-east, covering $11 \%$ of the territory in June, $21 \%$ in July, and $31 \%$ in August. There was an alternation of the processes in June and July that characterizes circulation groups "Stationary position" and "Northern meridional." In addition, the territory was under the influence of the air of the eastern periphery of the Azores anticyclone during 25-28 June and 21-22 July. The average monthly temperature in July and August in central and south-eastern European Russia exceeded the long-term average by $5-7$ degrees. There was almost 
Table 3. Average deviation of temperature $\left({ }^{\circ} \mathrm{C}\right)(1)$ and precipitation (\%) (2) over European Russia in comparison with the period 1961-1990

\begin{tabular}{|c|c|c|c|c|c|c|c|c|c|c|c|}
\hline \multicolumn{2}{|c|}{ December } & \multicolumn{2}{|c|}{ January } & \multicolumn{2}{c|}{ February } & \multicolumn{2}{c|}{ March } & \multicolumn{3}{c|}{ April } & \multicolumn{3}{c|}{ May } \\
\hline $\mathbf{1}$ & $\mathbf{2}$ & $\mathbf{1}$ & $\mathbf{2}$ & $\mathbf{1}$ & $\mathbf{2}$ & $\mathbf{1}$ & $\mathbf{2}$ & $\mathbf{1}$ & $\mathbf{2}$ & $\mathbf{1}$ & $\mathbf{2}$ \\
\hline-1.2 & 120 & -3.6 & 104 & -0.9 & 123 & 0.3 & 135 & 1.7 & 77 & 3.0 & 115 \\
\hline
\end{tabular}

no rainfall (Table 4). On July 28, Mediterranean cyclone, which arrived to the southern borders of the European Russia, was unable to break the anticyclonic regime. The next Mediterranean cyclone arrived only on August 27, during the end of drought. The maximal area of extreme drought was in July (14\% of the territory) and August (12\% of the territory) (Fig. 2b). The drought in the Volga region was observed in four months. Severe drought in western European Russia appeared only in July. In the south of the European Russia, there was only mild and moderate drought, which began in July. The intensity of severe drought increased from May to August. The boundary of drought extended in August in northern regions of European Russia, where it has been never observed.
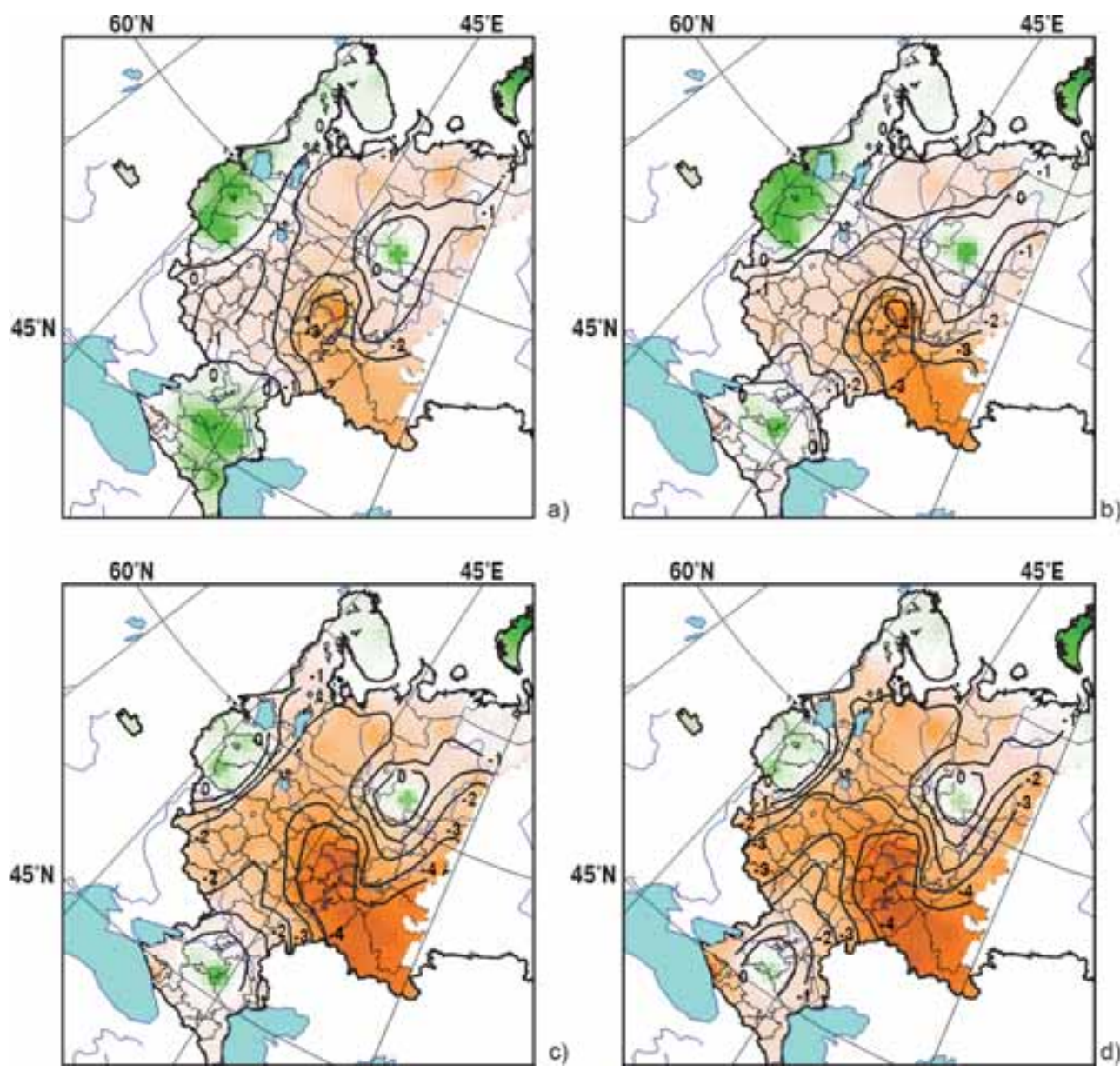

Fig. 2. Atmospheric drought in European Russia in: a) May b) June c) July and d) August, 2010 according to the Palmer Drought Severity Index. The contours show the intensity of drought 

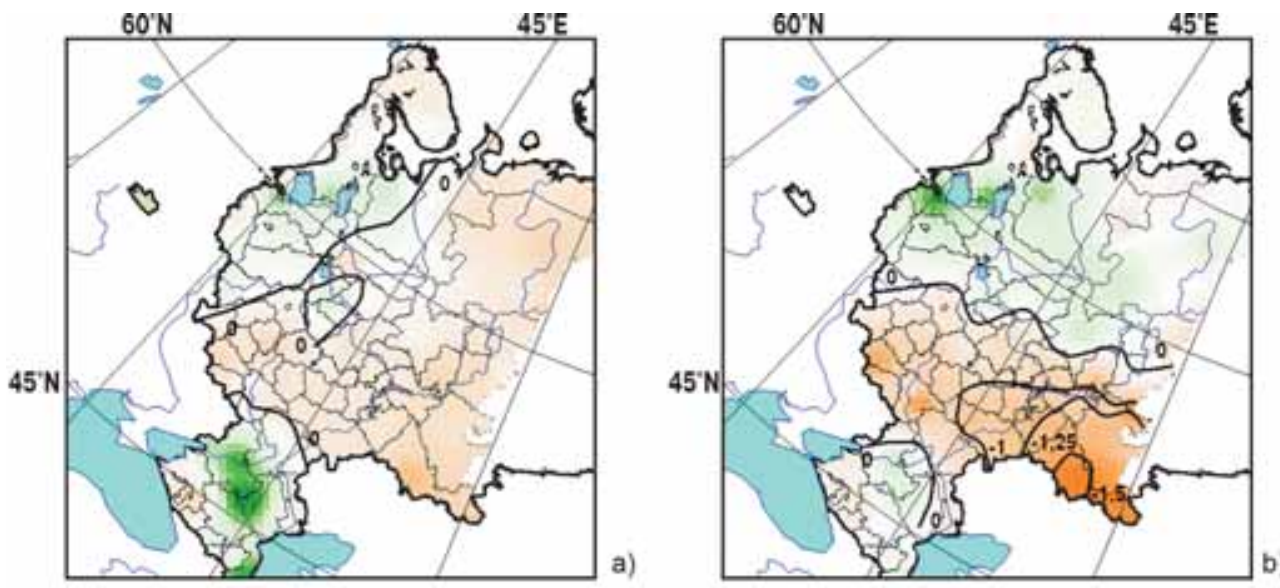

文
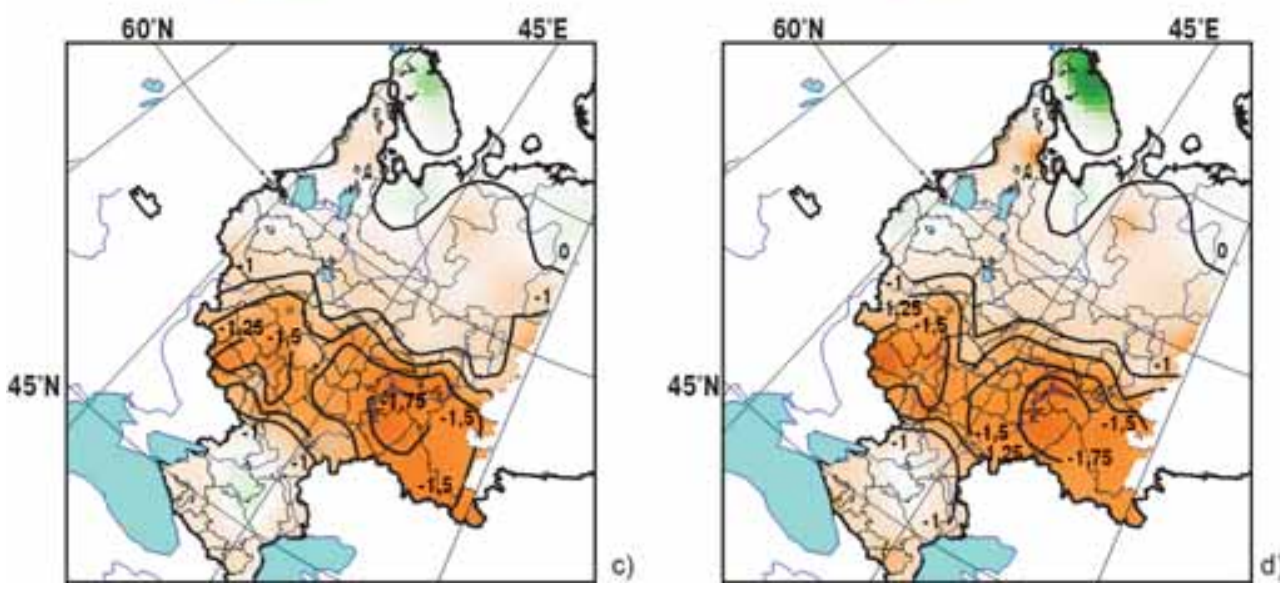

Fig. 3. Atmospheric drought in European Russia in: a) May b) May-June c) May-July and d) May-August, 2010 according to the normalized anomalies of HTC.

The contours show the intensity of drought

Table 4. Mean monthly air temperature and precipitation anomalies in the summer of 2010 on the territory of European Russia compared with the period 1961-1990

\begin{tabular}{|c|c|c|c|c|c|c|}
\hline \multirow{2}{*}{ Station } & \multicolumn{3}{|c|}{ Air temperature, ${ }^{\circ} \mathrm{C}$} & \multicolumn{3}{|c|}{ Precipitation, \% } \\
\hline & June & July & August & June & July & August \\
\hline Astrakhan & 3.4 & 3.9 & 4.0 & 24 & 0 & 5 \\
\hline Elista & 3.3 & 4.5 & 5.3 & 19 & 166 & 7 \\
\hline Primorsko-Akhtarsk & 2.7 & 3.0 & 4.7 & 82 & 52 & 55 \\
\hline Rostov-on-Don & 4.5 & 5.8 & 7.7 & 17 & 132 & 9 \\
\hline Tsimlyansk & 3.6 & 4.1 & 5.4 & 100 & 104 & 10 \\
\hline Aleksandrov Gay & 4.9 & 5.6 & 5.9 & 0 & 33 & 26 \\
\hline Oktyabr'skij Gorodok & 4.7 & 6.4 & 6.3 & 1 & 33 & 20 \\
\hline Voronezh & 4.2 & 6.8 & 7.1 & 52 & 46 & 52 \\
\hline Kamennaya Steppe & 5.0 & 7.0 & 7.3 & 4 & 35 & 55 \\
\hline Samara & 4.9 & 6.6 & 6.8 & 9 & 2 & 51 \\
\hline Tambov & 4.0 & 7.3 & 6.5 & 48 & 15 & 100 \\
\hline Makhachkala & 2.4 & 2.4 & 2.8 & 27 & 15 & 7 \\
\hline
\end{tabular}




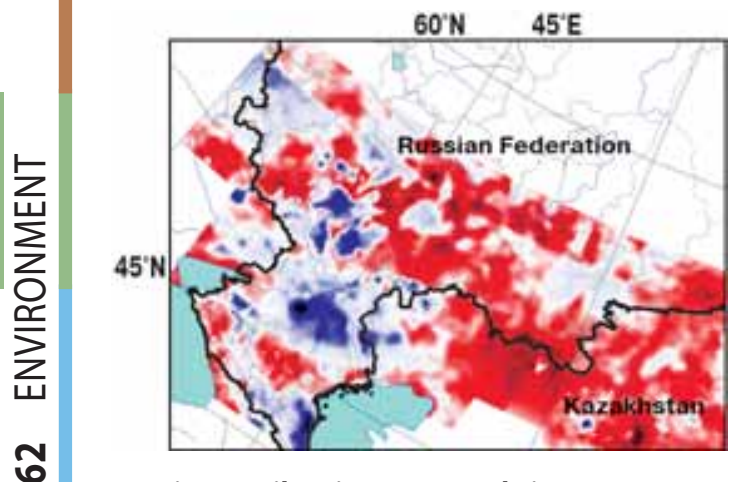

Fig. 4. Soil moisture anomaly in May 2010 (negative anomaly in red)

prevailing easterly and southeasterly winds in May and June contributed to the transfer of warm air from North Kazakhstan in the Volga region.

Based on the analysis of fluctuations of the European sector atmospheric circulation in the period from 1899, we assume that drought can be expected in European Russia in the near future due to the increasing duration of the blocking events in the recent years (Fig. 5).

The abnormally hot weather over European Russia in 2010 has beaten the previous temperature record of a hot season in Western Europe in the summer 2003 due to its intensity, duration, and spatial extent. The temperature maxima of the historical records for 500 years have been exceeded on more than $50 \%$ of the territory of European Russia. The ensemble calculations show that, over the next 40 years, the probability of such abnormalities may increase 5-10 times. However, despite these estimates, the probability of this phenomenon occurrence in the same region is very small until the middle of this century [Barriopedro et al., 2011].

\section{CONCLUSIONS}

It can be argued that the area of drought depends on the method of detection. According to the normalized anomalies of the Selyaninov Hydrothermal Coefficient and the Palmer index, the largest area of severe drought in European Russia was in 1972 and 1939.

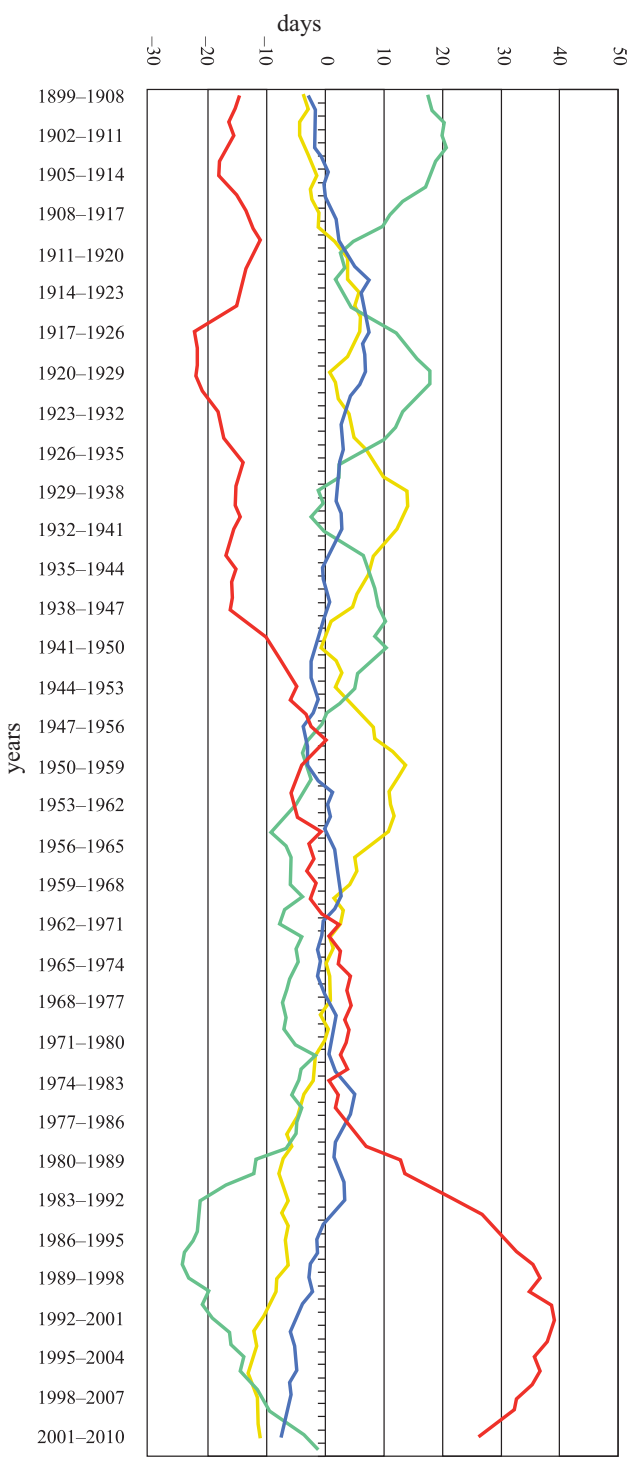

Fig. 5. 10-year moving averages of the circulation groups anomalies duration in European Russia. Western zonal group is denoted by yellow line, Northern meridional group - by green line, Southern meridional group - by blue line, and Stationary position group - by red line

The cold winter of 2010, which prevented the recharge of soil moisture due to snow melting and spring moisture deficits, had an impact on the occurrence of drought conditions in the central part of European Russia in May.

Based on the above results, we argued that the drought in 2010 began in May in 
the Volga region and was observed here for four months. During June-August, a severe drought spread in all directions. The intensity of drought has increased from May to August. The drought boundary extended in August to the northern regions of European Russia, where it has been never seen. The greatest impact of summer drought of 2010 happened in the south-eastern regions of European Russia. In the south of European Russia, a strong and extreme drought was not observed.

According to the circulation conditions dynamics in the period from 1899, we can expect droughts in European Russia in the near future due to the increasing duration of the blocking process in the recent years.

\section{ACKNOWLEDGEMENT}

This work was supported by the project "Desertification of arid lands of southern Russia in the context of climate change" of the Program for Basic Research Department of Earth Sciences № 13 and by the RFBR grant № 11-05-00573.

\section{REFERENCES}

1. Barriopedro D., Fischer E.M., Luterbacher J., Trigo R.M., Garcia-Herrera R. (2011) The Hot Summer of 2010: Redrawing the Temperature Record Map of Europe. Science. 332, 220-224.

2. Blunden J., Arndt D.S., Baringer M.O. (2011) State of the Climate in 2010. Bull. Amer. Meteor. Soc. Volume 92. Issue 6. Pp. S1-S236.

3. Cherenkova E.A. (2012) Analysis of extensive atmospheric drought features in the south of the European Russia. Arid Ecosystems. Arid Ecosystems. V. 18. №4 (53). Pp. 13-21. (in Russian).

4. Cherenkova E.A., Kononova N.K. (2012) Analysis of severe atmospheric drought in 1972 and 2010. Macrocirculation conditions of their formation over the European part of Russia // The Works of MGO. Issue 565. Pp. 165-187. (in Russian).

5. Cherenkova E.A. (2007) Dynamics of Severe Atmospheric Droughts in European Russia. // Russian Meteorology and Hydrology, Springer. Vol. 32. № 11. Pp. 675-682. Original Russian Text published in Meteorologiya i Gidrologiya, 2007, № 11, pp. 14-25.

6. Dai A., Trenberth K.E., and Qian T. (2004) A global data set of Palmer Drought Severity Index for 1870-2002: Relationship with soil moisture and effects of surface warming. J. Hydrometeorology, 5, 1117-1130.

7. Dole R., Hoerling M., Perliwitz J., Eischeid J., Prgion P., Zhang T., Quan X.-W., Xu T., Murray D. (2011) Was there a basis for anticipating the 2010 Russian heat wave? Geophys. Res. Lett. 38. L06702.

8. Drozdov O.A. (1980) Droughts and dynamics of moistening. L.: Gidrometeoizdat. 93 p. (in Russian).

9. Dzerdzeevskii B.L. (1968) Circulation mechanisms in the Northern Hemisphere atmosphere in 20-th century. Data of meteorological studies. Circulation of Atmosphere. International geophysical year. Institute of Geography of the USSR Academy of Sciences and 
Interagency Geophysical Committee of the Presidium of the USSR Academy of Sciences. M. 240. (In Russian with English summary and contents).

10. Dzerdzeevskii B. (1962) Fluctuations of Climate and of General Circulation of the Atmosphere in extra-tropical latitudes of the Northern Hemisphere and some problems of dynamic climatology. TELLUS, XIV, No 3. pp. 328-336.

11. Dzerdzeevskii B.L., Kurganskaya, V.M. and Vitvitskaya, Z.M. (1946) Classification of circulation mechanisms over the Northern Hemisphere and characteristics of synoptic seasons. Works of Scientific Institutes of the USSR Hydrometeorological Service, Series 2. Synoptic Meteorology. Issue 21. Central Forecast Institute. M.-L Gidrometizdat, Moscow, 80 p. (in Russian).

12. Frolov A.V., Strashnaya A.I. (2011) On the 2010 drought and its impact on productivity of crops. Proceedings of the joint meeting of the Presidium of the Council of Scientific and Technical Research Council of Roshydromet and the Russian Academy of Sciences "Research on the Theory of the Earth's climate". "Analysis of abnormal weather conditions in Russia in the summer of 2010". M. Triada LTD. Pp. 22-31. (in Russian).

13. Galarneau T.J., Hamill T.M., Dole R.M., Perlwitz J.A. (2012) Multiscale Analysis of the Extreme Weather Events over Western Russia and Northern Pakistan during July 2010. Mon. Wea. Rev., 140, 1639-1664.

14. Grumm Richard H. (2011) The Central European and Russian Heat Event of July-August 2010 // Bulletin of the American Meteorological Society. Volume 92. Issue 10. Pp. 12851296.

15. Hong C.-C., Hsu H.-H., Lin N.-H., Chiu H. (2011) Roles of European blocking and tropicalextratropical interaction in the 2010 Pakistan flooding. Geophys. Res. Lett. 38. L13 806.

16. Ivanova A.R., Shakina N.P., Skriptunova E.N., Bogaevskaya N.I. (2011) Comparison of dynamic characteristics of a blocking anticyclone in the summer of 2010 with the earlier episodes. Proceedings of the joint meeting of the Presidium of the Council of Scientific and Technical Research Council of Roshydromet and the Russian Academy of Sciences "Research on the Theory of the Earth's climate". "Analysis of abnormal weather conditions in Russia in the summer of 2010". M. Triada LTD. Pp. 65-71. (in Russian).

17. Kononova N.K. (2009) The classification of circulation mechanisms of the Northern Hemisphere by BL Dzerdzeevskii. A.B. Shmakin (Ed.). Moscow, Publ. "Voentekhizdat", 370 p. (in Russian).

18. Lau William K. M., Kim K. (2012) The 2010 Pakistan Flood and Russian Heat Wave: Teleconnection of Hydrometeorological Extremes. J. Hydrometeor. 13. 392-403.

19. Loginov V.F. (2002) Droughts, their possible causes and preconditions of predictions. // Natural processes: geographical, ecological and socio-economic aspects. Moscow: Publ. NIENAS. Pp. 107-124. (in Russian).

20. Meshcherskaya A.V., Mirvis V.M., Golod M.P. (2011) The drought of summer 2010 against the background of long-term changes in the aridity over bread-basket region in the European territory of Russia. The Works of MGO. Issue 563. Pp. 94-121. (in Russian). 
21. Mokhov I.I. (2011) The anomalous summer 2010 in the context of the overall climate change and its anomalies. Proceedings of the joint meeting of the Presidium of the Council of Scientific and Technical Research Council of Roshydromet and the Russian Academy of Sciences "Research on the Theory of the Earth's climate". "Analysis of abnormal weather conditions in Russia in the summer of 2010". M. Triada LTD. Pp. 41-47. (in Russian).

22. Naeimi, V., Bartalis Z., Wagner W. (2009) ASCAT soil moisture: An assessment of the data quality and consistency with the ERS scatterometer heritage. Journal of Hydrometeorology. Volume 10, Issue 2. Pp. 555-563.

23. Palmer W. C. (1965) Meteorological drought. U.S. Department of Commerce Research Paper 45, 65 p.

24. Rahmstorf S. and Coumou D. (2011) Increase of extreme events in a warming world. PNAS. Vol. 108. № 44. Pp. 17905-17909.

25. Rauner Yu.L. (1981) Climate and productivity of crops. Moscow. Publ. "Science". 164 p. (in Russian).

26. Schubert S., Wang H., Suarez M. (2011) Warm Season Subseasonal Variability and Climate Extremes in the Northern Hemisphere: The Role of Stationary Rossby Waves. J. Climate. Volume 24. Issue 18. Pp. 4773-4792.

27. Selyaninov G.T. (1928) On the agricultural evaluation of climate // The Works of the Agricultural Meteorology. No. 20. Pp. 165-177. (in Russian).

28. Semenov S.M. (2012) Methods of an assessment of consequences of climate change for physical and biological systems. Moscow: Roshydromet. 511 p. (in Russian).

29. Zoidze E.K., Khomyakova T.V. (2000) Evaluation of dry events in the Russian Federation. // The Works of ARRIAM. No. 33. Pp. 118-133. (in Russian).

30. Zolotokrylin A.N., Titkova T.B. (2012) Satellite climatic extremes index of dryland. Arid Ecosystems. V. 18. № 4 (53). Pp. 5-12. (in Russian).

31. Zolotokrylin A.N., Vinogradova V.V., Cherenkova E.A. (2007) The dynamics of droughts in the European Russia in a situation of global warming. Problems of ecological monitoring and modeling of ecosystems - S.-P. Gidrometeoizdat. T. 21. Pp. 160-181. (in Russian).

32. Ulanova E.S., Strashnaya A.I. (2000) Droughts in Russia and their impact on productivity of crops // The Works of ARRIAM. № 33. Pp. 64-83. (in Russian).

33. Volodin E.M. (2011) On the nature of some extreme anomalies of summer temperature. Proceedings of the joint meeting of the Presidium of the Council of Scientific and Technical Research Council of Roshydromet and the Russian Academy of Sciences "Research on the Theory of the Earth's climate". "Analysis of abnormal weather conditions in Russia in the summer of 2010". M. Triada LTD. Pp. 48-57. (in Russian). 


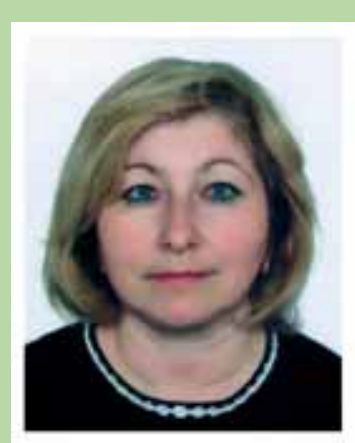

Elena A. Cherenkova studied at the Faculty of Computational Mathematics and Cybernetics at Moscow State University. Since January 2000, she has been a scientist of the Institute of Geography RAS. She received her PhD degree in Geography in 2009. The focus of her research is on climate change, drought dynamics, and displacement of arid zones boundaries.

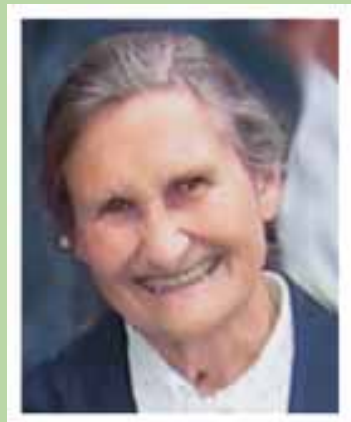

Nina K. Kononova graduated from the Faculty of Geography of Moscow State University in 1957 as a "geographer-climatologist". In 1957-1961, she was a postgraduate student at the Institute of Geography of the USSR, Academy of Sciences (scientific advisor B.L. Dzerdzeevskii); She holds a PhD degree in Geography since 1965. The area of her interests is Atmospheric Circulation (http://www.atmosphericcirculation.ru).

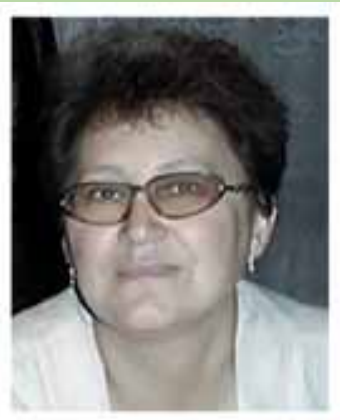

Nadiya R. Muratova graduated in 1981 from the Department of Applied Mathematics of Samarkand State University and obtained her Master's degree (Diploma). Since September 1981, she has been a researcher at the Institute of Mathematics and Mechanics of the Kasakh Academy of Sciences and, since September 1991, at the Space Research Institute. In 1997, she received her PhD degree. Now she is Head of the Department "Technologies of Space Monitoring". Her research interests are: creation of GIStechnologies and development of the methods of remote sensing application for agriculture and ecology. Main publications: Monitoring and assessment of spring crops in Kazakhstan (2006, with co-authors); Improved modeling of soil organic carbon in a semiarid region of Central East Kazakhstan using EPIC (2010, with co-authors); A remote sensing based discrimination between climate/human-induced vegetation changes in Central Asia (with co-authors). 